Didelphys (Peramys) Iheringi, sp. n.

Colours and proportions exactly as in D. americana, Müll. (=D. tristriata, auct.), but only about half the size of that species.

Dimensions of a male in spirit :-

Head and body 77 millim. ; tail 43 ; hind foot 14 ; ear 6.3 ; skull, basal length $22 \cdot 5$; first three molars, length $4 \cdot 2$.

Hab. Rio Grande do Sul (Dr. H. von Thering).

$$
\text { Didelphys (Peramys) Henseli, sp. n. }
$$

Size intermediate between that of the $D$. brevicaudata and the $D$. sorex and Theringi groups. Colour dark grizzled grey along the whole upper surface, deep rufous on the sides and belly. Ears small, reaching when laid forward only halfway towards the eye. Mammæ about twenty-five in number, five central, and about ten pairs of lateral ones.

Dimensions of the type (an adult female, in spirit) :-

Head and body 106 millim.; tail 62 (extreme tip imperfect); hind foot 15.5 ; skull, length 27 ; three anterior upper molars $4 \cdot 4$.

Hab. Rio Grande do Sul (Dr. H. von Ihering).

This is no doubt the intermediate species described but not named by Hensel *, and I have therefore, at the suggestion of Dr. von Ihering, named it after that eminent mammalogist.

\title{
MISCELLANEOUS.
}

Note on Lophopus Lendenfeldi.

To the Editors of the Annals and Magazine of Natural History.

Gentlemen,- - The facts narrated in the letter of Mr. Whitelegge at p. 62 of the January Number of your Journal have been also brought to my notice in detail in a letter from himself, and more generally in one signed by two gentlemen, Messrs. J. Douglas Ogilby and John Brazier, F.L.S., whom I understand to be members of the staff of the Australian Museum, Sydney; and I have before me a printed extract from the 'Ashton Reporter' of March 20th, 1886, describing in general terms a fine Polyzoan and a method of preserving it in such a way as to show the parts much as those of the specimen described by me as Lophopus Lendenfeldi in the 'Journal of the Linnean Society' (Zoology), xx. p. 62, pl. ii. It may be almost unnecessary for me to say that I was in total ignorance of these facts when I wrote my paper, but such is the case; and I regret very greatly the injustice which I have thus unconsciously done to Mr. Whitelegge, who has fully vindicated his title to the honours of

$$
\text { * Abh. Ak. Berl. 1872, p. } 123 .
$$


discovering and preserving the specimens on which the description of the species was based. The details as to discovery and preservation, as given in my paper, require modification in this sense; and I hope that future students will give $\mathrm{Mr}$. Whitelegge the great credit due to him, not only for bringing this very fine species to the knowledge of the scientific world, but for the great skill shown in the preparation of the specimens which came under my notice.

I am, Gentlemen,
Yaryport, Cumberland,
January 16th, 1888.
STuathfully,

On Glyphastræa sexradiata, Lonsdale, $s p$. By P. Martin

Duncan, M.B. (Lond.), F.R.S., \&c.

In a communication to the Geological Society (Quart. Journ. Geol. Soc. vol. xliii. Feb. 1887, p. 24) I described Glyphastrcea Forbesi, Ed. \& Haime, sp., and stated that its alliance with Columnaria sexradiata, Lonsd. (Quart. Journ. Geol. Soc. vol. i. 1845, p. 497), was very close, and I gave the form the name Glyphastrcea sexradiata, Lonsd., sp. At the time a very careful search was made for the specimen described and figured by Lonsdale, but it could not be found, although all the other types of Lonsdale's N.-American tertiary species which were given to me by Sir C. Lyell were still in my possession. After the publication of the paper a coral was found by the Curator of King's College Museum ; it was one of a number of fossils given by me to the College about twelve years since. This coral had upon it in Lonsdale's handwriting, with which I am very familiar, "Columnastrcea sexradiata." On examining this coral, which is in the museum of the College in which I am Professor of Geology, I find that the distinctions between it and a specimen of Glyphastrcea Forbesi, Ed. \& H., sp., are not specific, but are due to growth. This last-named species was later in time of description than Lonsdale's, and therefore Glyphastrcea sexradiata, Lonsdale, sp., is the correct name for Columnaria sexradiata, Lonsd., and Glyphastrcea Forbesi, Ed. \& Haime, sp. I am glad to be able to do this justice to the late Mr. Lonsdale. Since I examined the coral, last March, it has been cut without my knowledge or sanction.

King's College, Jan. 16, 1888.

\section{On the first Changes in the Fecundated Ovum of Lepas.}

By Prof. M. Nussbaum.

During the author's residence on the coast of California he was able to obtain an abundance of material. All the ova in the same animal are at the same stage of development, but the animals are very abundant and the breeding-season lasts for several months, so that by continued preparation the different stages may be obtained in different animals.

The author's description commences with the stage at which the copulation of the male and female cells is effected, and the masses of ova enclosed in a thin homogeneous sac protrude from the orifices of the oviducts into the space within the shell on each side of the head. The ova are small and numerous, ovate, with a blunt and 


\section{$2 \mathrm{BHL}$ Biodiversity Heritage Library}

1888. "Note on Lophopus Lendenfeldi." The Annals and magazine of natural history; zoology, botany, and geology 1, 159-160.

https://doi.org/10.1080/00222938809460695.

View This Item Online: https://www.biodiversitylibrary.org/item/84521

DOI: https://doi.org/10.1080/00222938809460695

Permalink: https://www.biodiversitylibrary.org/partpdf/63644

\section{Holding Institution}

Smithsonian Libraries

\section{Sponsored by}

Smithsonian

\section{Copyright \& Reuse}

Copyright Status: Public domain. The BHL considers that this work is no longer under copyright protection.

This document was created from content at the Biodiversity Heritage Library, the world's largest open access digital library for biodiversity literature and archives. Visit BHL at https://www.biodiversitylibrary.org. 